\title{
Örgüt Kültürü ve Örgüt İkliminin Örgütsel Sessizlik Üzerindeki Etkisinin Analizi *
}

\section{Analysis of the Impact of Organizational Culture and Organizational Climate on Organizational Silence}

Ayhan Yalçınsoy ${ }^{a^{* *}}$

${ }^{a}$ Dr., Diyarbakır/Türkiye

ORCID: 0000-0002-0510-1586

\section{MAKALE BİLGİSI}

\section{Makale Geçmişi:}

Başvuru tarihi: 21 Mayıs 2018

Düzeltme tarihi: 01 Temmuz 2018

Kabul tarihi: 17 Temmuz 2018

\section{Anahtar Kelimeler:}

Örgüt Kültürü

Örgüt İklimi

Örgütsel Sessizlik

\section{ART ICLE INFO}

\section{Article history:}

Received 21 May 2018

Received in revised form 01 July 2018

Accepted 17 July 2018

\section{Keywords:}

Organization Culture

Organisation Climate

Organisational Silence
ÖZ

Bu çalışmanın amacı, sağlık sektörü çalışanlarının örgüt kültürü ve örgüt iklimi algılarının örgütsel sessizlik algıları üzerinde etkisi olup olmadığını belirlemektir. Araştırmanın örneklemini Adana ilinde görev yapan sağlık sektörü çalışanı 411 personel oluşturmaktadır. Araştırmada elde edilen veriler, araştırmanın amacı doğrultusunda çeşitli istatistik metot ve test teknikleri (frekans dağılımı, t-testi, ANOVA, regresyon, korelasyon) kullanılarak PSPP 0.10 .2 istatistik paket programı yardımıyla değerlendirilmiştir. Anlamlılık düzeyi 0.05 olarak kabul edilmiştir. Araştırmada çalışanların örgüt kültürü ve örgüt iklimi algıları ile örgütsel sessizlik algıları arasında pozitif yönlü ve zayıf bir ilişki olduğu sonucuna ulaşılmıştır. Ayrıca örgüt kültürünün örgütsel sessizlik üzerinde zayıf da olsa bir etkisinin olduğu tespit edilmiştir.

\section{Giriş}

İnsanlığın varlığı ile birlikte hayat bulan örgütlerin esas unsuru olan insan, önemini kaybetmeden varlığını sürdüre gelmiş̧ir. Modern yönetim tekniklerinin gelişmesiyle birlikte insana verilen değer bir kat daha artmıştır. Çünkü modern yönetim teknikleri, işi yapanın işi en iyi bildiğini, işle ilgili muhtemel sorunlar ya da iyileştirmeler konusunda en uygun fikir ve düşünceye sahip olduğunu kabul etmektedir.

Rekabet koşullarının her geçen gün sertleştiği küresel pazarda her türlü geliştirme, iyileştirme ve sorun çözümünde hızlı olmak işletmelere rekabet üstünlüğü sağlayacaktır. Geliştirme, iyileştirme ve sorun çözümünde işletmelere hız katacak olan şey ise bizzat kendi bünyesinde çalışan işgörenlerin yaptıkları iş ya da iş yeri ile ilgili bilgi, fikir ve düşüncelerini dile getirmesidir. Ancak yapılan araştırmalar (Beheshtifar vd., 2012; Botero vd., 2009; Çakıcı, 2007, 2010; Morrison vd., 2000; Nikolaou vd., 2011; Uçar, 2016; Vakola vd., 2005; Yalçınsoy, 2017) işgörenlerin çeşitli nedenlerle iş ya da iş yeriyle ilgili bilgi, fikir ve düşüncelerini ifade etmediklerini göstermektedir.

$\mathrm{Bu}$ çalışmada toplum hayatında çok önemli bir yeri olan sağlık sektörü çalışanlarının sessiz kalıp kalmadıkları, içinde

\footnotetext{
* Bu çalışma, 2017 y1lında Dicle Üniversitesi Sosyal Bilimler Enstitüsü tarafindan kabul edilen “Örgüt Kültürü ve Örgüt İkliminin Örgütsel Sessizlik Üzerindeki Etkisinin Analizi” adlı Doktora tezinden türetilmiş ve 22-23 Eylül 2016 tarihlerinde İstanbul'da düzenlenen 1.Sosyal Bilimlerde Gelecek İçin Bilimsel İşbirliği Konferansında bildiri olarak sunulmuştur.

** Sorumlu yazar/Corresponding author.

e-posta: ayhanyalcinsoy@gmail.com
} 
bulundukları örgüt kültürü ve ikliminin örgütsel sessizlik davranışları üzerinde bir etkisi var $\mathrm{m} ı$ sorusuna cevap aranmıştır.

\section{2. Örgüt Kültürü}

Örgüt kültürü, belirli bir grup tarafindan icat edilmiş, keşfedilmiş veya dişsal uyum ve içsel bütünleşme sorunlarını çözerken geliştirilmiş, geçerliliği kabul edilmiş ve bu yüzden yeni üyelere de bu problemler karşısında düşünme, hissetme ve eylem olarak tavsiye edilen bir temel varsayımlar sistemidir (Bitsani, 2013; Cameron vd, 2006; Köse vd., 2001).

Örgüt kültürü, işgörenlerin tutum ve davranışlarını biçimlendiren baskın değerler ve inançlar (Güçlü, 2003: 148) olması nedeniyle bireylere yapması gereken şeyler ve sergilemesi gereken davranışlar konusunda duygu ve sezgi kazandırır. $\mathrm{Bu}$ kazanımlar ile bireyler örgüt içinde nasıl davranacaklarına karar verirler.

Örgüt kültürü ile ilgili Pettigrew, Hofstede, Schein, Schneider, Beach, Miles ve Snow, Pheysey, Cameron ve Quinn, Handy gibi araştırmacı ve teorisyenler çalışmalar yapmışlardır (Yaman vd., 2014: 37). Bu çalışmalardan Quinn ve Cameron tarafından geliştirilen rekabetçi değerler modelinde (Şekil 1) örgüt kültürü, klan, adhokrasi, hiyerarşi ve pazar olmak üzere dört boyutta incelenmiştir (Cameron vd., 2006).

Şekil 1. Rekabetçi Değerler Modeli

\begin{tabular}{|c|c|}
\hline \multicolumn{2}{|c|}{ Esneklik ve Sağduyu (Flexsiblity and Discretion) } \\
\hline $\begin{array}{c}\text { TIP: Klan Kültürü } \\
\text { BASKIN NITELIKLER: } \\
\text { Birleştiricilik, katılımcilik, takm } \\
\text { çalışması, aile bilinci } \\
\text { LIDER STiLI: } \\
\text { Danışman, kolaylaştırıc1, } \\
\text { atalik rolü } \\
\text { KAYNAŞTIRMA: } \\
\text { Sadakat, gelenek, kişilerarası } \\
\text { bağllilik } \\
\text { STRATEJKK YÖNTEM: } \\
\text { Insan kaynaklarını geliştirmeye, } \\
\text { bağllilığa, morale yönelik }\end{array}$ & $\begin{array}{l}\text { TİP: Adhokrasi Kültürü } \\
\text { BASKIN NITELIKLLR: } \\
\text { Girişimcilik, yaratıcllk, uyum } \\
\text { sağlama } \\
\text { LIDER STILI: } \\
\text { Girişimci, yaratıc1, risk alıcı } \\
\text { KAYNAŞTIRMA: } \\
\text { Girişimcilik, esneklik, risk } \\
\text { STRATEJiK YÖNTEM: } \\
\text { Yaratıcilığa,büyümeye, yeni } \\
\text { kaynaklara yönelik }\end{array}$ \\
\hline $\begin{array}{l}\text { İç Odaklhk ve } \\
\text { Entegrasyon } \\
\text { (Internal focus and } \\
\text { Integration) }\end{array}$ & $\begin{array}{l}\text { Diș Odaklılık ve Farklılaşma } \\
\text { (External Focus and } \\
\text { Differentiation) }\end{array}$ \\
\hline TİP: Hiyerarși Kültürü & TİP: Pazar F yltürü \\
\hline $\begin{array}{c}\text { BASKIN NITELIKLER: } \\
\text { Düzen, kurallar ve } \\
\text { düzenlemeler, yeknesaklik } \\
\text { LIDER STILI: } \\
\text { Koordinatör, idareci } \\
\text { KAYNAŞTIRMA: } \\
\text { Kurallar, politikalar ve yöntemler } \\
\text { STRATEJIK YÖNTEM: } \\
\text { Dengeye, tahmin edilebilirliği } \\
\text { düzenli işlere yönelik }\end{array}$ & $\begin{array}{c}\text { BASKIN NITELIKLER: } \\
\text { Rekabet, amaca ulaşma } \\
\text { LIDER STILİ: } \\
\text { Kararlı, iş bitirici, } \\
\text { KAYNAŞTIRMA: } \\
\text { Hedefe yönelim, üretim, rekabet } \\
\text { STRATEJIK YÖNTEM: } \\
\text { Rekabet gücüne ve Pazar üstünlügüne } \\
\text { yönelik }\end{array}$ \\
\hline & \\
\hline
\end{tabular}

\subsection{Klan Kültürü}

Geniş bir aileye benzeyen bu kültürün hâkim olduğu işletmelerde, ortak değerlerin benimsenmesi, takım ruhu ve çalışması, çalışanların işletme ile bütünleşmesi ve kendilerini geliştirmeleri teşvik edilir. Çalışanlar arasında dostça ilişkiler, sadakat ve bütünleşme vardır. Liderler emir komuta etmekten ziyade yol gösterici durumundadırlar. Bu kültürün hâkim olduğu örgütlerde tüketici duyarlılığını sağlamak ve insanların ilgisini çekmek başarının göstergesidir. Klan kültürünün egemen olduğu örgütlere sağlık kurumları, üniversiteler ve bazı endüstri firmaları örnek gösterilebilir (Aktaş vd., 2014; Cameron vd., 2006; Erdem, 2007; İşcan vd., 2007; Kuşcu, 2011).

\subsection{Adhokrasi Kültürü}

Kurumsal yapılaşma ve rehberliğin az olduğu, kişisel yaratıcılık ve yenilikçiliğin teşvik edildiği bir kültür tipidir. Dinamik ve yaratıcı bir ortamın var olduğu bu kültür türünde işgörenlerin deneyim, yenilik ve risk ile bütünleşmesi beklenmektedir. Adhokrasi kültürünün hâkim olduğu örgütler uzun vadede büyüme ve yeni kaynaklar temin etmeye çalışırlar. Tek ve yeni ürün ya da hizmet sunmak başarı anlamına gelmektedir. Adhokrasi kültürünün egemen olduğu örgütlere yazılım şirketleri ve danışmanlık şirketleri örnek gösterilebilir (Cameron vd., 2006; İşcan vd., 2007).

\subsection{Hiyerarşi Kültürü}

Temel endüstri sektöründeki uzun ömürlü işletmelerde görülebilen bu kültür tipinde, açık bir yetki sınırı, standart kurallar, süreçler, ileri düzeyde resmiyet ve yapılaşma mevcuttur. Liderler iyi birer koordinatör ve etkili birer organizatördürler. Örgütü bir arada tutan resmi kural ve politikalardır. İstikrarı sürdürmek hayati öneme haizdir ve güvenilir teslimat, düzgün programlama ve düşük maliyet başarının göstergesidir. Oto fabrikaları, doğal kaynak işletmeleri, dini, askeri ve resmi kurumlar hiyerarşi kültürünün egemen olduğu örgütlere örnek gösterilebilir (İşcan vd., 2007: 123).

\subsection{Pazar Kültürü}

Kararlı ve istekli liderlere sahip olan bu kültür tipindeki işletmeler piyasada önemli bir yere sahip olma eğilimi içerisindedirler. Üyeleri arasında kazanmaya dayalı bir bağ vardır ve kişiler kurumlarına kattığı değere göre sorumludurlar ve ödüllendirilirler. Uzun vadeli hedefleri olan bu kurumların liderleri hem üretken hem de sert rekabeti sevmektedirler. Pazara girme ve pazar payı elde etme başarının göstergesidir. Ayrıca pazar liderliği ve rekabetçi fiyatlandırma oldukça önemlidir. Pazar kültürünün egemen olduğu örgütlere danışmanlık firmaları, General Elektrik, Pfizer örnek gösterilebilir (Cameron vd., 2006; İşcan vd., 2007).

Cameron ve Quinn örgütsel yaşam döngüsünün en erken safhalarında, işletmelerde biçimsel yapı ve girişimcilik ile özdeşleşen adhokrasi kültürünün baskın olduğunu ifade etmişlerdir. Resmi politikalar ve yapılardan büyük oranda yoksundurlar ve genellikle tek, güçlü, vizyon sahibi bir lider tarafından yönlendirilirler. Zamanla geliştikçe, bu yönelim bir aile, güçlü aidiyet ve işletme ile özdeşleşmiş kişisel kimlik özellikleri taşıyan klan kültürüne doğru kayar. İşletme çalışanları, sosyal ve duygusal ihtiyaçlarının birçoğunu işletme içinde yerine getirirler ve topluluk ve kişisel dostluk duygusu vardır. İşletmenin büyümesiyle birlikte genellikle potansiyel bir kriz ortaya çıkar. Eninde 
sonunda genişleyen sorumlulukları kontrol altına alabilmek için yapıyı ve standart prosedürleri vurgulama ihtiyacı ile karşı karşıya kalınır. Hiyerarşi kültürüne geçiş yapmak için düzen ve öngörülebilirlik gereklidir. $\mathrm{Bu}$ yeniden yönlendirme genellikle bir zamanlar iş yeri ile özdeşleşmiş güler yüzlü işletme çalışanlarına, kişisel duyguyu kaybettiğini hissettirmekte ve kişisel memnuniyet azalmaktadır. Hiyerarşi yönelimi de sonuç olarak rekabetçilik, dış odaklılık ve verimlilik ile özdeşleşen pazar kültürüne odaklanılarak tamamlanmaktadır (Cameron vd., 2006: 53-54).

\section{3. Örgüt İklimi}

İklim genel olarak çevremizdeki şeyleri nasıl algıladığımıza dair paylaşılan alg1 olarak tanımlanabilir. Daha net bir tanımlama ile iklim, resmi ve gayri resmi işletme politikaları, uygulamaları ve prosedürlerinin paylaşılan algısıdır (Holloway, 2012; Zhang vd., 2010). Güçlü ise örgüt iklimini, işletme çalışanlarının davranışlarını etkileyen ve işgörenler tarafindan algılanan, kuruma hâkim olan ve kimliğini kazandıran özelliklerin tümü olarak tanımlamıştır (Güçlü, 2003: 155). Örgüt iklimi, işgörenlerin deneyimlediği politika, uygulama ve prosedürlerin paylaşılan algılamaları ve anlamları ile ödüllendirildiği gözlemlenen, desteklenen ve beklenen davranışlar olarak tanımlanabilir (Adeniji, 2011; Schneider vd., 2013).

Örgüt iklimi, örgüt üyelerinin kişisel değerleri ile örgüte ait değerler arasındaki uyumu ölçer. Kişilerin örgüt içindeki faaliyetlerin nasıl olması gerektiği ile ilgili beklentileriyle, bu beklentilerinin hangi ölçüde gerçekleştiğiyle alâkalı algılarının oluşturduğu hava olarak tanımlanabilir. İşgörenlerin örgüt kültürünü benimsemeleri durumunda örgüt ikliminin iyi, aksi durumda ise kötü ya da zayıf olduğu ifade edilir (Büte, 2011: 110).

Örgüt iklimi konusunda yapılan araştırmalarda örgüt ikliminin birçok boyutu üzerinde durulmuştur. Örgüt ikliminin boyutları örgütün faaliyet gösterdiği sektöre, yani yaptığı işe göre farklılık gösterebilmektedir. Örgüt ikliminin çok farklı boyutları olmasına rağmen örgütlerin kendi mensuplarının ihtiyaçlarına cevap verebilecek bir iklim meydana getirmeleri gerekmektedir. Örgüt iklimi boyutları birçok araştırmacı tarafindan farklı şekillerde ifade edilmiştir. İşçan ve Karabey, örgüt iklimini Üstün Desteği, İş Yükü Baskısı， Bağdaşıklık, İçsel Takdir ve Tarafsızlık olmak üzere beş boyutta ele almışlardır (İşcan vd., 2007).

\section{1. Üstün Desteği}

Yönetici desteği, yöneticilerin astların önemli kararların alınmasında katılımını teşvik eden, astlarıyla farklı fikirde olduklarında onlarla iletişim kuran, eylemlerini astlarına açıklayan, işlerinde özerk davranmalarına olanak sağlayan, işle ilgili sorunları çözmelerine yardım eden, yapılan iyi çalışmaları ödüllendiren fakat astların yaptıkları işleri sürekli denetlemekten sakınan davranışlarını kapsamaktadır (Çekmecelioğlu, 2011: 31).

Astların üstü ile iyi ilişkiler içinde olması işletme içinde güven ve bağlılık ortamı oluşturacaktır. Böyle bir ortamda ise astlar üstlerinin kendilerine yardımcı olduğunu ve işletme içinde kendilerine değer verildiğini düşüneceklerdir.

\subsection{Iş̧ Yükü Baskısı}

İş yükü kavramı, işgörenin iş yerinde kendisine verilen işin normalden fazla olduğunu düşünmesidir (Keser, 2005: 105). Bireyin kendisinden belirli bir zaman diliminde yapması gerekenden daha fazla iş yapması istendiğine dair algısıdır. Böyle bir durumda işgören üzerinde oluşan zaman ve iş baskısı, strese ve tükenmişliğe neden olacaktır. Bu durum ise motivasyon kaybına, yapılan işe karşı duyarsızlaşmaya, işaile çatışmasına (Turgut, 2011: 160), örgütün ikliminin müsait olduğu durumlarda işgören sessizliğine neden olabilmektedir.

\subsection{Bağdaşıklık}

Bağdaşıklık bir grubun mensuplarının bir birini çekme derecesini ifade etmektedir. Bir kurumun bağdaşıklık düzeyini o işletmenin işgörenlerinin fikir ve düşüncelerini sansürsüz bir şekilde ifade edebileceklerine inanma düzeyi belirlemektedir (İşcan vd., 2007: 184). Bağdaşıklık düzeyi yüksek olan bir işletmede kişisel güven, zihinsel rahatlık, emniyette olma duygusu, alınabilecek risklerde yalnız olunmadığı hissi gelişir ve böylece kendini güvende hisseden bireyler bilgi, fikir ve düşüncelerini rahatlıkla paylaşabilirler.

\section{4. İçsel Takdir}

Kişileri motive edici etkenlerden olan takdir ve ödüllendirme Vroom'un beklenti teorisi açısından ele alındığında çalışanların örgütün yararına bilgi, fikir ve düşüncelerini ifade etmesi bekleniyorsa, çalışanlarda, fayda elde edilen bilgi, fikir ve düşüncelerinden dolayı ödüllendirileceği algısının oluşturulması gerekir. Ancak maddi olarak verilen ödüllerin bir noktadan sonra motive edici gücünü kaybetmesi nedeniyle çalışanları içsel motive edici ödüllerin verilmesi gerekmektedir. Bu tür ödüller bireyin kendine olan saygısını artırır ve bu öz saygının gereği olarak birey motive edilmiş olur (Karaköse vd., 2006: 5). Örneğin işgörenin işini yaparken daha fazla özerk olması, kendisini geliştirmesi için firsatlar verilmesi, bunları yapabilmesi için zaman tahsis edilmesi, işgörenin idari yüklerinden arındırılması gibi durumlarda içsel takdir algıları artabilir ve bu durumda örgüt yararına bilgi, fikir ve düşüncelerini paylaşması sağlanabilir.

\subsection{Tarafsizlık}

Genellikle kuralların ayrım yapılmadan uygulandığı, maliyet ve kârın eşit olarak dağıtıldığı, eşitliğin temel olduğu bir örgütte adalet algısının yüksek olduğu, böyle adil bir ortamda ise kişilerin kararların alınış şeklini düşünmeden veya eşitlik konusunda bir endişe taşımadan kendi işlerine odaklanabildiği ifade edilebilir. Kendi işine odaklanan bireylerin ise işleri konusunda kendilerini geliştirmeleri ve uzmanlaşmaları olağan bir durumdur. İşlerinde uzmanlaşmış bireylerin işletme ile ilgili alınacak kararlarda söz sahibi olması ve fikirlerine değer verilmesi işlemsel adalet 
açısından önem arz etmektedir. Bu bağlamda çalışanların fikirlerinin tarafsız bir şekilde değerlendirilmesi örgütsel iklim açısından olumlu bir durumdur (İşcan vd., 2007: 184).

\section{4. Örgütsel Sessizlik}

İlk defa 1970'li y1llarda yönetim literatüründe yer bulan işgören sessizliği kavramı Hirschman tarafından pasif ancak örgütsel bağllılı ile aynı anlamda ve yapıcı bir tepki olarak ele alınmıştır. 2000'li yılların başına kadar yönetim bilimciler sessizliği örgütsel bağlllığa denk tutmuşlardır (Çakıcı, 2007; Eroğlu vd., 2011; Uçar, 2016). Örgüt içindeki gelişmeler karşısında işgörenlerin sessiz kalmalarını, çalışanların örgütte olan bitenleri kabullenmesi olarak değerlendirmiş ve bunu da bağlllı̆̆ın bir boyutu olarak ele almışlardır. 2000 yılında Morrison ve Milliken tarafından yapılan çalışmada sessizliğin örgütsel gelişim ve değişim için bir tehdit ve işgörenlerin fikir ve düşüncelerini özgürce ifade edemedikleri bir durum olduğu ortaya koyulmuştur (Morrison vd., 2000).

Yapılan yazın taramasında birçok araştırmacı tarafından (Bogosian vd., 2013; Dedahanov vd., 2015; Kahveci vd., 2013; Morrison vd., 2000; Pinder vd., 2001; Van Dyne vd., 2003) örgütsel sessizlik kavramının, kişilerin örgütün durumuyla ilgili zihinsel, davranışsal ve duygusal ifadelerini söz konusu problem ya da durumu düzeltebilecek yetenekteki kişi ya da kişilerden bilinçli olarak saklaması olarak tanımlandığı görülmektedir.

Ülkemizde örgütsel sessizlik çalışmalarının öncülerinden Çakıcı (2007) ise örgütsel sessizliği, işgörenlerin iş ya da iş yeriyle ilgili iyileştirme ve geliştirme adına teknik veya davranışsal konularla ilgili fikir ve düşüncelerini bilinçli olarak esirgemesi olarak ifade etmiştir.

Çok boyutlu bir yapı olan sessizlik, geri çekilme, korku ya da işbirliği ile güdülenmektedir (Bogosian vd., 2013; Dedahanov vd., 2015; Kumar vd., 2015; Şimşek vd., 2014; Van Dyne vd., 2003). Bu üç farklı güdü ile güdülenen sessizlik, kabullenici sessizlik, korunma amaçlı sessizlik ve koruma amaçlı sessizlik olmak üzere üç alt boyuttan oluşmaktadır (Van Dyne vd., 2003: 1362).

\subsection{Kabullenici Sessizlik}

Kabullenici sessizlik çalışanların bilgi, görüş ve fikirlerini geri çekilmeye dayalı olarak örgütten saklamasıdır (Durak, 2012: 50). Kabullenici sessizlikte işgörenler mevcut konumdan geri çekilirler ve durumu değiştirmek için konuşmaya, yardım etmeye ya da girişimde bulunmaya gönüllü değildirler (Ehtiyar vd., 2008; Ülker vd., 2009; Van Dyne vd., 2003).

İşgörenin, fikrine değer verilmeyeceğini ve bu nedenle herhangi bir şeyi değiştirmeyeceğini düşünmesi, konu ile ilgili kendini yeteriz hissetmesi, hal ve hareketlerini alınan kararlara ve oluşturulan normlara göre biçimlendirmesi ve bunları benimsemesi kabullenici sessizlik olarak ifade edilebilir (Van Dyne vd., 2003: 1366). Kabullenici sessizlik sergileyen işgörenler örgüt içindeki koşulları olduğu gibi kabul etmenin yanında söz konusu koşulları düzeltmeye yönelik çözümlerinde pek farkında değildirler (Pinder vd., 2001; Tayfun vd., 2013).

\subsection{Korunma Amaçlı Sessizlik}

Morrison ve Milliken örgütsel sessizliğin temelinde motive edici olgunun korku olduğunu ve korunmaya dayalı sessizliği, korkuya bağlı olarak kendini koruma amacı ile ilgili fikir, bilgi ve düşünceleri saklama olarak ifade etmişlerdir (Erdoğan, 2011; Morrison vd., 2000; Tayfun vd., 2013).

Korunma amaçlı sessizlik, işgörenlerin örgüt içinde mevcut bir sorun, konu ya da durum ile ilgili fikir ve düşüncelerini açıklaması halinde karşılaşabilecekleri tepkilerden korkmaları sonucu kendilerini korumak amaciyla bilgi, fikir ve düşüncelerini saklaması olarak tanımlanabilmektedir (Acaray vd., 2015; Eroğlu vd., 2011; Van Dyne vd., 2003). Kendini koruma maksadıyla yapılan bu davranış, sorunların yok sayılmasına, kişisel hataların saklamasına ve yeni fikirlerin gizlenmesine neden olmaktadır (Çakıcı, 2010; Durak, 2012; Gül vd., 2011).

\subsection{Koruma Amaçl1 Sessizlik}

Koruma amaçlı sessizlik işgörenin örgütünü koruma güdüsü ve diğer çalışanları koruma güdüsü olmak üzere iki şekilde ortaya çıkmaktadır. İşgörenler her iki durumda da kişisel çıkarlarından ziyade örgütün ya da diğer işgörenlerin yararını ön planda tutma eğilimi gösterirler. Dolayısıyla işgörenler korku temelli kendisini koruma davranışı yerine örgütün ya da diğer işgörenlerin faydasını ön planda tutarak bir fedakârlık sergilemektedirler (Acaray vd., 2015; Kumar vd., 2015; Şehitoğlu vd., 2010).

Koruma amaçlı sessizlikte işgörenler korunma amaçlı sessizliğin aksine konuştuklarında karşılaşılabilecekleri olumsuzluklardan daha çok başkalarının olumsuzluklarla karşılaşmaması için sessiz kalmaktadır (Durak, 2012; Van Dyne vd., 2003). O halde koruma amaçlı sessizlik, yaşanabilecek sıkıntılara katlanmak, sizlanmadan ve şikayetçi olmadan çalışmaya devam etmek başkaları ya da örgüt yararına sergilenecek bir davranış şeklidir denilebilir (Tayfun vd., 2013; Van Dyne vd., 2003). Diğer bir ifadeyle işgörenler birlik ve beraberliğin devamı adına muhalif olabilecek görüşlerini açıklamaktan kaçınabilirler (Çakıcı, 2010; Durak, 2012).

\section{Yöntem}

\subsection{Araştırmanın Problemi}

Modern yönetim teknikleri işgörenlerin bilgi, beceri ve kapasitelerinin, bulundukları örgütlerdeki faaliyetlerin iyileştirilmesinde oldukça önemli bir etken olduğunu ortaya koymaktadır. Bununla birlikte yapılan araştırmalar, işgörenlerin öz güvenlerine rağmen fikirlerini ifade etmekte tereddüt yaşadıklarını, ilgili konuda tartışmaya girmenin ya da fikirlerini açıça söylemenin riskli bir konu olduğunu kanaatinde olduklarını ortaya koymaktadır (Çakıcı, 2007; Milliken vd., 2003; Pinder vd., 2001; Premeaux vd., 2003). 
Söz konusu durumlardan dolayı işgörenler sessizliği tercih etmektedirler. Daha önceleri uyum ve itaatin bir göstergesi olarak algılanan işgören sessizliği günümüzde tepki gösterme ve geri çekilme davranışı olarak kabul edilmektedir (Bildik, 2009; Gül vd., 2011).

Yazın incelendiğinde örgütsel sessizliğin işgörenlerin örgütsel bağlılığını, moralini, güvenini, iş doyumunu ve örgütsel süreçleri olumsuz olarak etkilediği (Milliken vd., 2003), örgütsel sosyalleşmeyi ve uyumu engellediği, işgörenlerin stres düzeyini artırdığı ve sabotaj gibi tehlikeli girişimlere yol açabildiği (Çakıcı, 2008; Ehtiyar vd., 2008) belirlenmiştir.

Bu çalışmada ise "Örgüt kültürü ve örgüt ikliminin örgütsel sessizlik üzerinde etkisi var mıdır?” sorusunun cevabı aranmıştır.

\subsection{Araştırmanın Amacı}

$\mathrm{Bu}$ çalışmanın amacı, örgüt kültürü ve örgüt ikliminin örgütsel sessizlik üzerindeki etkisinin yanı sıra işgörenlerin içinde bulundukları örgüt kültürü ve örgüt ikliminin sessizlik davranışları üzerinde etkisinin olup olmadığını bir alan araştırması ile ortaya koymaktır.

\subsection{Araştırma Modeli}

Çalışma örgüt kültürü ve örgüt iklimi ile örgütsel sessizlik arasındaki ilişkinin ortaya konulmasına yönelik olarak aşağıdaki araştırma modeli (Şekil 2) ve hipotezleri içermektedir.

Şekil 2. Araştırmanın Modeli

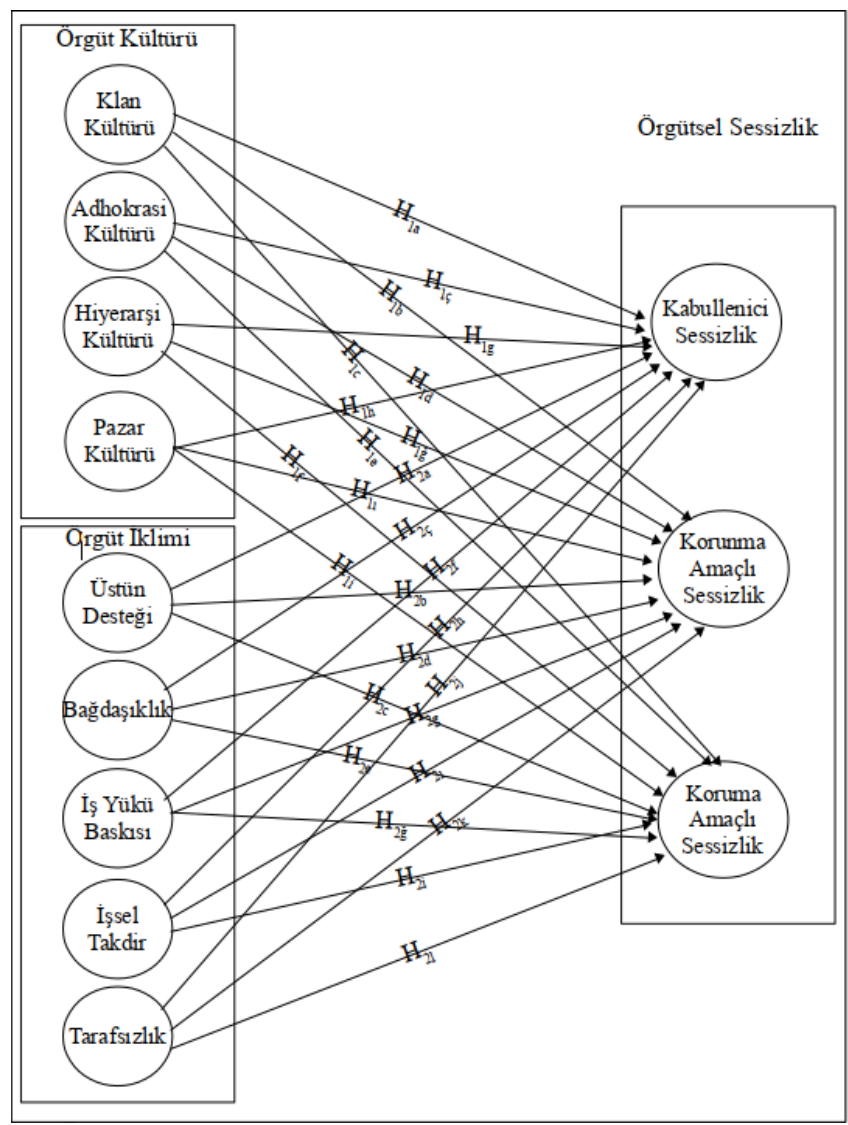

H1: Örgüt kültürü ile örgütsel sessizlik arasında anlamlı ilişki vardır.

H1a: Klan kültürü ile kabullenici sessizlik arasında anlamlı ilişki vardır.

H1b: Klan kültürü ile korunma amaçlı sessizlik arasında anlamlı ilişki vardır.

H1c: Klan kültürü ile koruma amaçlı sessizlik arasında anlamlı ilişki vardır.

H1ç: Adhokrasi kültürü ile kabullenici sessizlik arasında anlamlı ilişki vardır.

H1d: Adhokrasi kültürü ile korunma amaçlı sessizlik arasında anlamlı ilişki vardır.

H1e: Adhokrasi kültürü ile koruma amaçlı sessizlik arasında anlamlı ilişki vardır.

H1f: Hiyerarşi kültürü ile kabullenici sessizlik arasında anlamlı ilişki vardır.

H1g: Hiyerarşi kültürü ile korunma amaçlı sessizlik arasında anlamlı ilişki vardır.

H1 ğ: Hiyerarşi kültürü ile koruma amaçlı sessizlik arasında anlamlı ilişki vardır.

H1h: Pazar kültürü ile kabullenici sessizlik arasında anlamlı ilişki vardır.

H11: Pazar kültürü ile korunma amaçlı sessizlik arasında anlamlı ilişki vardır.

H1i: Pazar kültürü ile koruma amaçlı sessizlik arasında anlamlı ilişki vardır.

H2: Örgüt iklimi ile örgütsel sessizlik arasında anlamlı ilişki vardır.

H2a: Üstün desteği ile kabullenici sessizlik arasında anlamlı ilişki vardır.

H2b: Üstün desteği ile korunma amaçlı sessizlik arasında anlamlı ilişki vardır.

H2c: Üstün desteği ile koruma amaçlı sessizlik arasında anlamlı ilişki vardır.

H2ç: Bağdaşıklık ile kabullenici sessizlik arasında anlamlı ilişki vardır.

H2d: Bağdaşıklık ile korunma amaçlı sessizlik arasında anlamlı ilişki vardır.

H2e: Bağdaşıklık ile koruma amaçlı sessizlik arasında anlamlı ilişki vardır.

H2f: İş yükü baskısı ile kabullenici sessizlik arasında anlamlı ilişki vardır.

H2g: İş yükü baskısı ile korunma amaçlı sessizlik arasında anlamlı ilişki vardır.

H2̆ğ İş yükü baskısı ile koruma amaçlı sessizlik arasında anlamlı ilişki vardır.

H2h: İçsel takdir ile kabullenici sessizlik arasında anlamlı ilişki vardır.

H21: İçsel takdir ile korunma amaçlı sessizlik arasında anlamlı ilişki vardır.

H2i: İçsel takdir ile koruma amaçlı sessizlik arasında anlamlı ilişki vardır.

H2j: Tarafsızlık ile kabullenici sessizlik arasında anlamlı ilişki vardır.

H2k: Tarafsızlık ile korunma amaçlı sessizlik arasında anlamlı ilişki vardır. 
H21: Tarafsızlık ile koruma amaçlı sessizlik arasında anlamlı ilişki vardır.

\subsection{Evren ve Örneklem}

Araştırmamızın evrenini Adana ilinde çalışan ve örgütsel sessizlik davranışı sergiledikleri varsayılan, 4098 doktor, 4059 hemşire ve 3087 diğer personel olmak üzere toplam 11.244 sağlık çalışanı oluşturmaktadır. Çalışma evreni ise bir kamu ve üç özel hastane çalışanı 800 doktor, 790 hemşire ve 700 diğer personel olmak üzere 2290 sağlık çalışanından oluşturmaktadır (Sağlık Bakanlığı Sağlık Araştırmaları Genel Müdürlüğü, 2016). Çalışma evrenini oluşturan tüm sağlık çalışanlarına ulaşılması hedeflenmiş ve geri dönen 411 anket geri dönüş oranına göre değerlendirmeye tabi tutulmuştur.

Araştırmaya katılan katılımcıların yaş, cinsiyet, medeni durum, eğitim durumu, görev unvanı ve çalışma süresi sorularına verdikleri cevaplar ve sayıları frekans ve yüzde analizi yapılarak yorumlanmıştır.

Tablo 1. Katılımcıların Demografik Özellikleri

\begin{tabular}{lcc}
\hline Cinsiyet & $\mathrm{n}$ & $\%$ \\
\hline Kadın & 197 & 47,93 \\
Erkek & 214 & 52,07 \\
\hline Yaş & $\mathrm{n}$ & $\%$ \\
\hline 30 yaş ve altı & 341 & 82,97 \\
31 yaş ve üzeri & 70 & 17,03 \\
\hline Medeni durum & $\mathrm{n}$ & $\%$ \\
\hline Evli & 142 & 34,55 \\
Bekar & 269 & 65,45 \\
\hline Ĕgitim Durumu & $\mathrm{n}$ & $\%$ \\
\hline Lise ve Altı & 120 & 29,2 \\
Üniversite ve Üzeri & 291 & 70,8 \\
\hline Görevi & $\mathrm{n}$ & $\%$ \\
\hline Doktor & 132 & 32,12 \\
Hemşire & 221 & 53,77 \\
Diğer & 58 & 14,11 \\
\hline İş Tecrübesi & $\mathrm{n}$ & $\%$ \\
\hline 5 y1l ve altı & 317 & 77,13 \\
6 y1l ve üzeri & 94 & 22,87 \\
\hline
\end{tabular}

Araştırmaya katılan toplamda 411 çalışanın Tablo 1'de de görüldüğü üzere 197'si (\% 48) kadın, 214'ü (\% 52) erkektir. Katılımcıların 341 'i (\% 83) 30 ve aşağı yaş aralığında iken 70 'i (\% 17) 31 ve üzeri yaş aralığındadır. Katılımcıların 142'si (\% 34,5) evli, 269'u (\% 65,5) bekârdır. Katılımcıların eğitim düzeylerine bakıldığında lise ve altı (\% 29) 120 kişi, üniversite ve üstü eğitim düzeyine sahip olanlar (\% 71) 291 kişidir. İş tecrübelerine göre katılımcıların 317'si (\%77) 5 yıl ve alt1, 94'ü (\% 23) 6 yıl ve üstü iş tecrübesine sahiptir. Görev dağılımına göre ise katılımcıların 132'si (32) idareci, 221'i (\% 54) memur ve 58'i (14) ise diğer pozisyonlarda görev yapmaktadır.

\subsection{Veri Toplama Arac1}

Araştırmada, demografik özellikleri belirlemek üzere değişkenler anket formu aracıyla katılımcılara yöneltilmiştir. Anket formunda 5'li Likert tipi ölçek kullanılmıştır.

(i) Demografik Bilgiler Formu: Katılımcılara ait demografik bilgileri toplamaya yönelik olan bu ankette; yaş, cinsiyet, medeni durum, eğitim ve iş tecrübesi gibi özellikler yer almaktadır. (ii) Örgüt Kültürü Ölçeği: $\mathrm{Bu}$ ölçek örgüt kültürünü belirlemek için Quinn ve Cameron (2005) tarafından geliştirilmiştir. Her bir önerme için "Kesinlikle Katıliyorum", "Katılıyorum", "Kararsızım", "Katılmiyorum" ve "Kesinlikle Katılmiyorum" ifadelerini içeren 5'li Likert tipinde bir tercih listesi bulunmaktadır. Puanlamada önermelere verilen yanitlar "Kesinlikle Katıliyorum" ifadesinden "Kesinlikle Katılmıyorum ifadesine doğru 5-4-3-21 şeklinde puanlanmıştır. Anket için yapılan güvenilirlik analizinde Croncbach Alpha katsayısı 0.93 olarak bulunmuştur. Normal dağılım için çarpıklık ve basıklık değerleri -2 ve +2 arasında bulunmuş olup, dağılım normaldir.

(iii) Örgüt İklimi Ölçeği: Bu ölçek örgüt iklimini ölçmek için Koys ve Decotis (1991) ölçeği baz alınarak Montes vd (2004) tarafından geliştirilmiştir. Her bir önerme için "Kesinlikle Katılıyorum", "Katıliyorum", "Kararsızım", "Katılmıyorum" ve "Kesinlikle Katılmıyorum" ifadelerini içeren 5'li Likert tipinde bir tercih listesi bulunmaktadır. Puanlamada önermelere verilen yanitlar "Kesinlikle Katıliyorum" ifadesinden "Kesinlikle Katılmiyorum ifadesine doğru 5-4-3-2-1 şeklinde puanlanmıştır. Anket için yapılan güvenilirlik analizinde Croncbach Alpha katsayısı 0.85 olarak bulunmuştur. Normal dağılım için çarpıklık ve basıklık değerleri -2 ve +2 arasında bulunmuş olup, dağılım normaldir.

(iv) Örgütsel Sessizlik Ölçeği: Araştırmada kullanılan örgütsel sessizlik ölçeği olarak, Van Dyne, Ang ve Botero (2003) tarafından geliştirilmiştir. Her bir önerme için "Kesinlikle Katılıyorum", "Katılıyorum", "Kararsızım", "Katılmıyorum" ve "Kesinlikle Katılmıyorum" ifadelerini içeren 5'li Likert tipinde bir tercih listesi bulunmaktadır. Puanlamada önermelere verilen yanitlar "Kesinlikle Katıliyorum" ifadesinden "Kesinlikle Katılmıyorum ifadesine doğru 5-4-3-2-1 şeklinde puanlanmıştır. Anket için yapılan güvenilirlik analizinde Croncbach Alpha katsayısı 0.86 olarak bulunmuştur. Normal dağılım için çarpıklık ve basıklık değerleri -2 ve +2 arasında bulunmuş olup, dağılım normaldir.

\subsection{Verilerin Analizi}

Verilerin değerlendirilmesinde PSPP 0.10.2 istatistik analiz yazılımı kullanılmıştır. Araştırmada elde edilen veriler, araştırmanın amacı doğrultusunda çeşitli istatistik metot ve test teknikleri (frekans dağılımı, ortalama, t-testi, ANOVA, regresyon, korelasyon) kullanılarak yorumlanmıştır. Verilerin değerlendirilmesi, katılımcıların her bir soruya verdikleri cevapların toplam puanları üzerinden yapılmıştır. İstatistikî anlamlılık düzeyi $\mathrm{p}<0.05$ olarak kabul edilmiştir.

\section{Bulgular ve Yorumlar}

Örgüt Kültürü alt boyutları (Klan Kültürü, Adhokrasi Kültürü, Pazar Kültürü ve Hiyerarşi Kültürü) ile Örgütsel Sessizlik alt boyutları (Kabullenici Sessizlik, Korunma Amaçlı Sessizlik ve Koruma Amaçlı Sessizlik) arasındaki ilişkileri incelemek maksadıyla yapılan korelasyon analizi sonuçları Tablo 1'de verilmiştir. 
Tablo 2: Örgüt Kültürü, Örgüt İklimi ve Örgütsel Sessizlik Arasındaki Korelasyon Analizi

\begin{tabular}{|c|c|c|c|c|c|c|c|c|c|c|c|c|c|c|c|c|}
\hline Değişkenler & & 1 & 2 & 3 & 4 & 5 & 6 & 7 & 8 & 9 & 10 & 11 & 12 & 13 & 14 & 15 \\
\hline $\begin{array}{l}\text { Örgüt } \\
\text { Kültürü(1) }\end{array}$ & $\begin{array}{l}\text { Pearson } \\
\mathrm{p}(2 \text { yanl1) }\end{array}$ & 1,00 & & & & & & & & & & & & & & \\
\hline $\begin{array}{l}\text { Klan } \\
\text { Kültürü (2) }\end{array}$ & $\begin{array}{l}\text { Pearson } \\
\text { p }(2 \text { yanli) }\end{array}$ & $\begin{array}{l}, 87 \\
, 000\end{array}$ & 1,00 & & & & & & & & & & & & & \\
\hline $\begin{array}{l}\text { Adhokrasi } \\
\text { Kültürü (3) }\end{array}$ & $\begin{array}{l}\text { Pearson } \\
\mathrm{p}(2 \text { yanl })\end{array}$ & $\begin{array}{l}, 90 \\
, 000\end{array}$ & $\begin{array}{l}, 74 \\
, 000\end{array}$ & 1,00 & & & & & & & & & & & & \\
\hline $\begin{array}{l}\text { Pazar } \\
\text { Kültürü (4) }\end{array}$ & $\begin{array}{l}\text { Pearson } \\
\mathrm{p}(2 \text { yanlı) }\end{array}$ & $\begin{array}{c}, 86 \\
, 000 \\
\end{array}$ & $\begin{array}{c}, 62 \\
, 000 \\
\end{array}$ & $\begin{array}{l}, 71 \\
, 000\end{array}$ & 1,00 & & & & & & & & & & & \\
\hline $\begin{array}{l}\text { Hiyerarşi } \\
\text { Kültürü (5) }\end{array}$ & $\begin{array}{l}\text { Pearson } \\
\mathrm{p}(2 \text { yanl1) }\end{array}$ & $\begin{array}{l}, 89 \\
, 000 \\
\end{array}$ & $\begin{array}{l}, 74 \\
, 000 \\
\end{array}$ & $\begin{array}{l}, 72 \\
, 000 \\
\end{array}$ & $\begin{array}{l}, 70 \\
, 000 \\
\end{array}$ & 1,00 & & & & & & & & & & \\
\hline $\begin{array}{l}\text { Örgüt } \\
\text { İklimi (6) }\end{array}$ & $\begin{array}{l}\text { Pearson } \\
\mathrm{p}(2 \text { yanl1) }\end{array}$ & $\begin{array}{l}, 79 \\
, 000 \\
\end{array}$ & $\begin{array}{l}, 76 \\
, 000 \\
\end{array}$ & $\begin{array}{l}, 66 \\
, 000 \\
\end{array}$ & $\begin{array}{l}, 66 \\
, 000 \\
\end{array}$ & $\begin{array}{l}, 73 \\
, 000 \\
\end{array}$ & 1,00 & & & & & & & & & \\
\hline $\begin{array}{l}\text { Üstün } \\
\text { Desteği (7) }\end{array}$ & $\begin{array}{l}\text { Pearson } \\
\mathrm{p}(2 \text { yanl })\end{array}$ & $\begin{array}{l}, 79 \\
, 000 \\
\end{array}$ & $\begin{array}{l}, 73 \\
, 000 \\
\end{array}$ & $\begin{array}{l}, 71 \\
, 000 \\
\end{array}$ & $\begin{array}{l}, 59 \\
, 000 \\
\end{array}$ & $\begin{array}{l}, 78 \\
, 000 \\
\end{array}$ & $\begin{array}{l}, 84 \\
, 000 \\
\end{array}$ & 1,00 & & & & & & & & \\
\hline $\begin{array}{l}\text { İş Yükü } \\
\text { Baskısı (8) }\end{array}$ & $\begin{array}{l}\text { Pearson } \\
\mathrm{p}(2 \text { yanlı) }\end{array}$ & $\begin{array}{l}-, 12 \\
, 014 \\
\end{array}$ & $\begin{array}{l}-, 09 \\
, 074\end{array}$ & $\begin{array}{l}-, 19 \\
, 000 \\
\end{array}$ & $\begin{array}{l}-, 10 \\
, 041 \\
\end{array}$ & $\begin{array}{l}-, 04 \\
, 409 \\
\end{array}$ & $\begin{array}{l}, 08 \\
, 104 \\
\end{array}$ & $\begin{array}{l}-, 19 \\
, 000\end{array}$ & 1,00 & & & & & & & \\
\hline Bağdaşıklık (9) & $\begin{array}{l}\text { Pearson } \\
\mathrm{p}(2 \text { yanl })\end{array}$ & $\begin{array}{l}, 72 \\
, 000 \\
\end{array}$ & $\begin{array}{l}, 68 \\
, 000 \\
\end{array}$ & $\begin{array}{l}60 \\
, 000 \\
\end{array}$ & $\begin{array}{l}, 62 \\
, 000 \\
\end{array}$ & $\begin{array}{l}, 63 \\
, 000 \\
\end{array}$ & $\begin{array}{l}, 74 \\
, 000 \\
\end{array}$ & $\begin{array}{l}, 60 \\
, 000 \\
\end{array}$ & $\begin{array}{l}-, 05 \\
, 289 \\
\end{array}$ & 1,00 & & & & & & \\
\hline İçsel Takdir (10) & $\begin{array}{l}\text { Pearson } \\
\mathrm{p}(2 \text { yanl1 })\end{array}$ & $\begin{array}{l}, 68 \\
, 000 \\
\end{array}$ & $\begin{array}{l}, 64 \\
, 000 \\
\end{array}$ & $\begin{array}{l}, 56 \\
, 000 \\
\end{array}$ & $\begin{array}{l}, 58 \\
, 000 \\
\end{array}$ & $\begin{array}{l}, 61 \\
, 000 \\
\end{array}$ & $\begin{array}{r}, 85 \\
, 000 \\
\end{array}$ & $\begin{array}{c}, 72 \\
, 000 \\
\end{array}$ & $\begin{array}{l}-, 16 \\
, 001 \\
\end{array}$ & $\begin{array}{c}, 52 \\
, 000 \\
\end{array}$ & 1,00 & & & & & \\
\hline Tarafsızlık (11) & $\begin{array}{l}\text { Pearson } \\
\text { p (2 yanl1) }\end{array}$ & $\begin{array}{l}59 \\
, 000\end{array}$ & $\begin{array}{l}56 \\
, 000 \\
\end{array}$ & $\begin{array}{l}51 \\
, 000\end{array}$ & $\begin{array}{l}52 \\
, 000\end{array}$ & $\begin{array}{l}, 47 \\
, 000\end{array}$ & $\begin{array}{l}, 81 \\
, 000\end{array}$ & $\begin{array}{c}, 64 \\
, 000\end{array}$ & $\begin{array}{l}-, 22 \\
, 000\end{array}$ & $\begin{array}{l}, 47 \\
, 000\end{array}$ & $\begin{array}{l}, 71 \\
, 000\end{array}$ & 1,00 & & & & \\
\hline $\begin{array}{l}\text { Örgütsel } \\
\text { Sessizlik(12) }\end{array}$ & $\begin{array}{l}\text { Pearson } \\
\text { p (2 yanl1) }\end{array}$ & $\begin{array}{l}28 \\
, 000\end{array}$ & $\begin{array}{l}, 17 \\
, 000\end{array}$ & $\begin{array}{l}31 \\
, 000\end{array}$ & $\begin{array}{l}31 \\
, 000\end{array}$ & $\begin{array}{l}, 20 \\
, 000\end{array}$ & $\begin{array}{c}, 24 \\
, 000\end{array}$ & $\begin{array}{c}, 14 \\
, 004\end{array}$ & $\begin{array}{l}, 23 \\
, 000\end{array}$ & $\begin{array}{l}29 \\
, 000\end{array}$ & $\begin{array}{l}, 04 \\
419\end{array}$ & $\begin{array}{l}, 15 \\
, 002\end{array}$ & 1,00 & & & \\
\hline $\begin{array}{l}\text { Kabullenici } \\
\text { Sessizlik(13) }\end{array}$ & $\begin{array}{l}\text { Pearson } \\
\mathrm{p}(2 \text { yanl1) }\end{array}$ & $\begin{array}{l}, 13 \\
, 007\end{array}$ & $\begin{array}{l}, 05 \\
, 275\end{array}$ & $\begin{array}{l}, 18 \\
, 000\end{array}$ & $\begin{array}{l}, 24 \\
, 000\end{array}$ & $\begin{array}{l}, 01 \\
, 834\end{array}$ & $\begin{array}{l}, 15 \\
, 002\end{array}$ & $\begin{array}{l}, 00 \\
, 989\end{array}$ & $\begin{array}{l}, 09 \\
, 083\end{array}$ & $\begin{array}{l}, 14 \\
, 003\end{array}$ & $\begin{array}{c}, 02 \\
, 678\end{array}$ & $\begin{array}{l}, 24 \\
, 000\end{array}$ & $\begin{array}{c}, 80 \\
, 000\end{array}$ & 1,00 & & \\
\hline $\begin{array}{l}\text { Korunma Amaçlı } \\
\text { Sessizlik(14) }\end{array}$ & $\begin{array}{l}\text { Pearson } \\
\mathrm{p}(2 \text { yanl })\end{array}$ & $\begin{array}{l}, 21 \\
, 000 \\
\end{array}$ & $\begin{array}{l}, 13 \\
, 008 \\
\end{array}$ & $\begin{array}{c}, 29 \\
, 000 \\
\end{array}$ & $\begin{array}{l}, 17 \\
, 001 \\
\end{array}$ & $\begin{array}{l}, 14 \\
, 004 \\
\end{array}$ & $\begin{array}{l}, 13 \\
, 007 \\
\end{array}$ & $\begin{array}{r}, 09 \\
, 063 \\
\end{array}$ & $\begin{array}{l}, 14 \\
, 004 \\
\end{array}$ & $\begin{array}{l}, 23 \\
, 000 \\
\end{array}$ & $\begin{array}{l}-, 02 \\
, 655 \\
\end{array}$ & $\begin{array}{r}, 05 \\
, 356 \\
\end{array}$ & $\begin{array}{c}, 85 \\
, 000 \\
\end{array}$ & $\begin{array}{l}, 59 \\
, 000 \\
\end{array}$ & 1,00 & \\
\hline $\begin{array}{ll}\text { Koruma } & \text { Amaçlı } \\
\text { Sessizlik(15) } & \\
\end{array}$ & $\begin{array}{l}\text { Pearson } \\
\text { p (2 yanl1) }\end{array}$ & $\begin{array}{l}31 \\
, 000\end{array}$ & $\begin{array}{l}, 21 \\
, 000\end{array}$ & $\begin{array}{l}, 21 \\
, 000\end{array}$ & $\begin{array}{l}31 \\
, 000\end{array}$ & $\begin{array}{l}, 35 \\
, 000\end{array}$ & $\begin{array}{l}, 29 \\
, 000 \\
\end{array}$ & $\begin{array}{l}, 26 \\
, 000 \\
\end{array}$ & $\begin{array}{l}, 33 \\
, 000 \\
\end{array}$ & $\begin{array}{l}28 \\
, 000 \\
\end{array}$ & $\begin{array}{c}, 12 \\
, 019 \\
\end{array}$ & $\begin{array}{l}, 06 \\
, 251 \\
\end{array}$ & $\begin{array}{l}, 52 \\
, 000 \\
\end{array}$ & $\begin{array}{l}, 13 \\
, 009 \\
\end{array}$ & $\begin{array}{l}.17 \\
, 001 \\
\end{array}$ & 1,00 \\
\hline & Adet & 411 & 411 & 411 & 411 & 411 & 411 & 411 & 411 & 411 & 411 & 411 & 411 & 411 & 411 & 411 \\
\hline
\end{tabular}

Tablo 2 de görüldüğü üzere;

- Örgüt kültürü $(\mathrm{r}=0,28 \mathrm{p}<0.001)$ ve örgüt iklimi ( $\mathrm{r}=0,24$ $\mathrm{p}<0.001)$ ile örgütsel sessizlik arasında zayıf ve pozitif yönlü anlamlı ilişkiler bulunmuştur. Bu sonuca göre $\mathrm{H} 1$ ve $\mathrm{H} 2$ kabul edilmiştir.

- Klan kültürü ile korunma amaçlı $(\mathrm{r}=0.13 \mathrm{p}<0.05)$ ve koruma amaçlı sessizlik $(\mathrm{r}=0.021 \mathrm{p}<0.001)$ arasında zayıf ve pozitif yönlü anlamlı ilişkiler bulunmuştur. $\mathrm{Bu}$ sonuçlara göre $\mathrm{H} 1 \mathrm{a}$ hipotezi reddedilmiş, $\mathrm{H} 1 \mathrm{~b}$ ve $\mathrm{H} 1 \mathrm{c}$ hipotezleri ise kabul edilmiştir.

- Adhokrasi kültürü ile kabullenici sessizlik ( $r=0.18 \mathrm{p}<0.001)$, korunma amaçlı sessizlik $(r=0.29 \mathrm{p}<0.001)$ ve koruma amaçlı sessizlik $(\mathrm{r}=0.21 \mathrm{p}<0.001)$ arasında zayıf ve pozitif yönlü anlamlı ilişkiler bulunmuştur. Bu sonuçlara göre $\mathrm{H} 1 c ̧, \mathrm{H} 1 \mathrm{~d}$ ve H1e hipotezleri kabul edilmiştir.

- Hiyerarşi kültürü ile korunma amaçlı sessizlik ( $\mathrm{r}=0.14$ $\mathrm{p}<0.05)$ ve koruma amaçlı sessizlik $(\mathrm{r}=0.35 \mathrm{p}<0.001)$ arasında zayıf ve pozitif yönde anlamlı ilişkiler tespit edilmiştir. Bu sonuçlara göre H1f hipotezi reddedilmiş, $\mathrm{H} 1 \mathrm{~g}$ ve $\mathrm{H} 1 \breve{g}$ hipotezleri kabul edilmiştir.

- Pazar kültürü ile kabullenici sessizlik ( $\mathrm{r}=0.24 \mathrm{p}<0.001)$, korunma amaçlı sessizlik $(\mathrm{r}=0.17 \mathrm{p}<0.001)$ ve koruma amaçlı sessizlik $(\mathrm{r}=0.31 \mathrm{p}<0.001)$ arasında zayıf ve pozitif yönlü anlamlı ilişkiler tespit edilmiştir. Bu sonuçlara göre $\mathrm{H} 1 \breve{g}, \mathrm{H} 1 \mathrm{~h}$ ve H11 hipotezleri kabul edilmiştir

- Üstün desteği ile korunma amaçlı sessizlik $(r=0.26 \mathrm{p}<0.001)$ arasında zayıf ve pozitif yönlü anlamlı ilişkiler tespit edilmiştir. $\mathrm{Bu}$ sonuca göre $\mathrm{H} 2 \mathrm{a}$ ve $\mathrm{H} 2 \mathrm{~b}$ hipotezleri reddedilmiş, H2c hipotezi kabul edilmiştir.

- Bağdaşıklık ile kabullenici sessizlik ( $\mathrm{r}=0.14 \mathrm{p}<0.05)$, korunma amaçlı sessizlik $(\mathrm{r}=0.23 \mathrm{p}<0.001)$ ve koruma amaçlı sessizlik $(\mathrm{r}=0.28 \mathrm{p}<0.001)$ arasında zayıf ve pozitif yönlü ilişkiler anlamlı ilişkiler tespit edilmiştir. Bu sonuçlara göre $\mathrm{H} 2 c ̧, \mathrm{H} 2 \mathrm{~d}$ ve H2e hipotezleri kabul edilmiştir.

- İş yükü baskısı ile korunma amaçlı sessizlik $(\mathrm{r}=0.14 \mathrm{p}<0.05)$ ve koruma amaçlı sessizlik $(\mathrm{r}=0.33 \mathrm{p}<0.001)$ arasında zayıf ve pozitif yönlü anlamlı ilişkiler bulunmuştur. Bu sonuçlara göre $\mathrm{H} 2 \mathrm{f}$ hipotezi reddedilmiş, $\mathrm{H} 2 \mathrm{~g}$ ve $\mathrm{H} 2 \breve{\mathrm{g}}$ hipotezleri ise kabul edilmiştir.

- İçsel takdir ile koruma amaçlı sessizlik $(r=0.12 \mathrm{p}<0.05)$ arasında zayıf ve pozitif yönlü anlamlı ilişkiler bulunmuştur. $\mathrm{Bu}$ sonuca göre $\mathrm{H} 2 \mathrm{~h}$ ve $\mathrm{H} 21$ hipotezleri reddedilmiş, $\mathrm{H} 2 \mathrm{i}$ hipotezi ise kabul edilmiştir.

- Tarafsızlık ile kabullenici sessizlik $(\mathrm{r}=0.24 \mathrm{p}<0.001)$ arasında zayıf ve pozitif yönlü anlamlı ilişkiler bulunmuştur. Bu sonuca göre $\mathrm{H} 2 \mathrm{j}$ hipotezi kabul edilmiş, $\mathrm{H} 2 \mathrm{k}$ ve $\mathrm{H} 2 \mathrm{l}$ hipotezleri ise reddedilmiştir.

Örgüt kültürü ve örgüt ikliminin örgütsel sessizlik üzerinde ne ölçüde etkisinin olduğunu belirlemek için yapılan regresyon analizi sonuçları Tablo 3'de verilmiştir. 
Tablo 3. Örgüt Kültürü ve Örgüt İkliminin Örgütsel Sessizlik Arasındaki Regrasyon Analizi

\begin{tabular}{|c|c|c|c|c|c|c|c|c|}
\hline Bğmsz Değ. & B & $\begin{array}{l}\text { Std. } \\
\text { Hata }\end{array}$ & $\beta$ & $\mathrm{t}$ & $\mathrm{p}$ & $\begin{array}{c}\text { Düz. } \\
\mathrm{R}^{2}\end{array}$ & $\mathrm{~F}$ & $\begin{array}{c}P \\
\text { (Mod.) }\end{array}$ \\
\hline $\begin{array}{l}\text { Örgüt } \\
\text { Kültürü }\end{array}$ & 0,20 & 0,06 & 0,24 & 3,10 & .002 & \multirow[t]{2}{*}{0,08} & \multirow[t]{2}{*}{18,1} & \multirow[t]{2}{*}{.000} \\
\hline Örgüt İklimi & 0,05 & 0,08 & 0,05 & 0,67 & .506 & & & \\
\hline
\end{tabular}

Tablo 3 'te görüldüğü üzere model bir bütün olarak anlamlıdır $(\mathrm{F}=18,10 ; \mathrm{p}<0,001)$. Bu sonuca göre örgütsel sessizlik algıs1 üzerindeki değişimin \%8'nin bağımsız değişkenler örgüt kültürü ve örgüt iklimi tarafından açıkladığı söylenebilir. Örgütsel sessizlik algısı üzerinde örgüt kültürünün $(B=0,20)$ bir etkiye sahip olduğu ve örgüt kültürü algısındaki bir birimlik artışın örgütsel sessizlik algısında 20 birim artışa neden olacağı söylenebilir. Örgüt ikliminin ise örgütsel sessizlik üzerinde istatistiksel olarak anlamlı bir etkiye sahip olmadığı söylenebilir.

Araştırmada, örgüt kültürü, örgüt iklimi ve örgütsel sessizlik kavramlarının yaş, cinsiyet, eğitim durumu, medeni durum ve iş tecrübesi gibi demografik değişkenlerle yapılan farklılık analizlerinde;

(i) Yaşı 31 ve üzeri olanların örgüt kültürü düzeyi diğer yaş gruplarına göre daha yüksek bulgulanmıştır $(\mathrm{t}: 2.520, \mathrm{p}<0.001)$

(ii) Kadın çalışanların erkeklere göre örgüt iklimi ve örgütsel sessizlik düzeylerinin daha yüksek olduğu görülmüştür (t: -0.783, p<0.001; t: -1.309, p<0.001).

(iii) Lise ve altı eğitim düzeyine sahip çalışanların örgütsel sessizlik düzeyinin daha yüksek olduğu görülmüştür $(\mathrm{t}: 0.747, \mathrm{p}<0.001)$.

(iv) 6 yıl ve üzeri iş tecrübesine sahip çalışanların diğer gruba göre örgüt iklimi ve örgüt kültürü düzeylerinin daha yüksek olduğu görülmüştür ( $\mathrm{t}: 2.665, \mathrm{p}<0.001$; $\mathrm{t}: 2.191, \mathrm{p}<0.001)$.

(v) İş yerindeki pozisyonlarına yönelik olarak yapılan ANOVA analizi sonuçlarına göre, idareci pozisyonundaki çalışanların örgüt kültürü, örgüt iklimi ve örgütsel sessizlik düzeyleri memur ve diğer pozisyonlarda çalışanlara göre daha yüksek bulgulanmıştır (F: 0.92, P<0.005, F: 29.92, P<0.005, F: $9.80, \mathrm{P}<0.005)$.

\section{Sonuç ve Öneriler}

Çalışmada, örgüt kültürü, örgüt iklimi ve örgütsel sessizlik kavramları alt boyutları arasındaki ilişkiler ile birlikte araştırılmıştır. Yapılan analiz sonucunda sağlık sektörü çalışanlarının;

- OÖrgüt kültürü algıları ile örgütsel sessizlik algıları arasında anlamlı ilişkiler tespit edilmiştir.

- Klan kültürü algıları ile kabullenici sessizlik, korunma amaçlı sessizlik ve koruma amaçlı sessizlik algıları arasında pozitif yönlü anlamlı ilişkiler bulunmuştur. Bulunan sonuçlar daha önce yapılan araştırmalarda (Acaray vd., 2015; Aktaş vd., 2014) bulunan sonuçlarla uyuşmamaktadır. İnsanlar arası ilişkilere, katılımcılığa, takım ruhuna ve sadakate önem verilen klan kültüründe işgörenlerin kabullenici ve korunma amaçlı sessizlik alg1sı göstermemesi, koruma amaçlı sessizlik algısı göstermesi beklenmektedir (Aktaş vd., 2014; Çavuşoğlu vd., 2016).
Ahokrasi kültürü algıları ile kabullenici sessizlik, korunma amaçlı sessizlik ve koruma amaçlı sessizlik algıları arasında pozitif yönlü anlamlı ilişkiler bulunmuştur. Elde edilen sonuçlar konu ile ilgili daha önce yapılan çalışmaların (Acaray vd., 2015; Aktaş vd., 2014; Çavuşoğlu vd., 2016) sonuçları örtüşmemektedir.

Hiyerarşi kültürü algıları ile korunma amaçlı sessizlik ve koruma amaçlı sessizlik algıları arasında pozitif yönlü anlamlı ilişkiler bulunmuştur. Elde edilen sonuçlar konu ile ilgili daha önce yapılan çalışmaların (Aktaş vd., 2014; Çavuşoğlu vd, 2016; Yalçınsoy vd., 2016) sonuçları ile benzerlik göstermektedir.

Pazar kültürü algıları ile kabullenici sessizlik, korunma amaçlı sessizlik ve koruma amaçlı sessizlik algıları arasında pozitif yönlü anlamlı ilişkiler bulunmuştur. Elde edilen sonuçlar daha önce yapılan iki çalışmanın (Çavuşoğlu vd., 2016; Yalçınsoy vd., 2016) sonuçları ile örtüşmektedir. Ancak bireysellik ve amaca ulaşmanın önemli olduğu pazar kültüründe kabullenme ve korunma amaçlı sessizlik algıları beklenmemektedir (Acaray vd., 2015; Aktaş vd., 2014).

Örgüt iklimi algıları ile örgütsel sessizlik algıları arasında anlamlı ilişkiler tespit edilmiştir.

Üstün desteği algıları ile koruma amaçlı sessizlik algıları arasında pozitif yönlü anlamlı ilişkiler bulunmuştur. Elde edilen sonuçlar daha önce yapılan çalışma (Yalçınsoy vd., 2016) sonuçları ile ötüşmektedir.

- Bağdaşıklık algıları ile kabullenici sessizlik, korunma amaçlı sessizlik ve koruma amaçlı sessizlik algıları arasında pozitif yönlü anlamlı ilişkiler bulunmuştur. Elde edilen sonuçlar daha önce yapılan çalışma (Yalçınsoy vd., 2016) sonuçları ile ötüşmektedir.

İş yükü baskısı algıları ile korunma amaçlı sessizlik ve koruma amaçlı sessizlik algıları arasında pozitif yönlü anlamlı ilişkiler bulunmuştur. ilişki bulunmaktadır. Elde edilen sonuçlar daha önce yapılan çalışma (Yalçınsoy vd., 2016) sonuçları ile ötüşmektedir. İş yükü baskısı bireyin kendine verilen işin normalden fazla olduğuna dair inancıdır (Keser, 2005). İş yükü baskısı işgörende strese ve sonrasında motivasyon kaybı ve sessizliğe neden olmaktadır.

İçsel takdir algıları ile koruma amaçlı sessizlik algıları arasında pozitif yönlü anlamlı ilişkiler bulunmuştur. Kendisine yapacağı işlerle ilgili özerklik tanınması, kendisini geliştirmesi için firsatlar verilmesi, işgörenin idari yüklerden arındırılması içsel takdir algılarını artıracaktır (İşcan vd., 2007). Bu bağlamda içsel takdir düzeyi yüksek işgörenlerin kabullenici ve korunma amaçlı sessizlik algısı göstermesi beklenmez. Aksine bilgi, fikir ve düşüncelerini paylaşmaları beklenmektedir.

Tarafsızlık algıları ile kabullenici sessizlik arasında pozitif yönlü anlamlı ilişkiler bulunmuştur. Kuralların tarafsız bir şekilde uygulandığı, kârın ve maliyetin eşit bir şekilde dağıtıldığı örgütlerde eşitlik konusunda bir endişe veya alınan kararlarda bir taraf tutma söz konusu olmayacak ve işgören sadece kendi işine yönelerek işinde kendini geliştirip uzmanlaşabilecektir. Buna 
bağlı olarak işinde uzmanlaşmış ve adil bir ortamda çalışan kişilerin bilgi, fikir ve görüşlerini ifade etmeleri beklenmektedir. Tarafsızlığın yani eşitliğin baskın olduğu örgütlerde bulunan sonuca uygun olarak kabullenici sessizliğin görülmesi beklenmektedir.

- Yaş1 31 ve üzeri olanların örgüt kültürü düzeyinin diğer yaş gruplarına göre daha yüksek tespit edilmiştir. Ortaya çıkan bu sonuç çalışanların olgunlaştıkça örgütün çalışma koşullarını ve kültürünü öğrenip daha fazla uyum sağlayabildikleri şeklinde yorumlanabilir.

- Kadın çalışanların erkeklere göre örgüt iklimi ve örgütsel sessizlik düzeylerinin daha yüksek olduğu görülmüştür. $\mathrm{Bu}$ durumun kadın çalışanların örgüt iklimine uyum sağlama konusunda karakteristik özelliklerinden kaynaklandığı söylenebilir.

- $\quad$ Lise ve altı eğitim düzeyine sahip çalışanların örgütsel sessizlik düzeylerinin daha yüksek olduğu görülmüştür. $\mathrm{Bu}$ sonuç eğitim düzeyine bağlı olarak çalışanların örgüt içerisinde yaşadıkları problemlere karşı kendilerini ifade etme konusunda bir özgüven eksikliği şeklinde yorumlanabilir. Eğitim düzeyi arttıkça örgüt içi konular sıkıntılar karşısında daha duyarlı olma ve kendini ifade yeteneğinin de artacağı şeklinde değerlendirilebilir.

- 6 yıl ve üzeri iş tecrübesine sahip çalışanların diğer gruba göre örgüt iklimi ve örgüt kültürü düzeylerinin daha yüksek olduğu görülmüştür. Yapılan araştırmalarda da görüleceği üzere tecrübeli çalışanların örgüt kültürü ve örgüt iklimine adapte olabildikleri şeklinde yorumlanabilir.

Örgüt kültürünün örgüt örgütsel sessizlik üzerinde önemli ölçüde etkisinin olduğu söylenebilir. Bu sonuçtan yola çıkılarak uygun örgütsel kültür oluşturulduğunda örgütsel sessizlik düzeyinin düşürülebileceği söylenebilir.

Sonuç olarak yapılan çalışmalarla (Bagheri vd., 2012; Beheshtifar vd., 2012; Çakıcı, 2008; Durak, 2012; Ehtiyar vd., 2008; Karaca, 2013; Kılıç vd., 2013; Megenci, 2015; Milliken vd., 2003; Morrison vd., 2000; Şimşek vd., 2014) olumsuz etkileri ortaya konmuş olan örgütsel sessizlik ile etkili bir mücadele edilmesi hem işgörenler için hem de örgütler için büyük önem taşımaktadır. Örgütsel sessizliğin ortadan kaldırılması ile işgörenlerin yaşadığı olumsuzluklar ortadan kalkacak buna bağlı olarak işgörenlerin sorunların çözümü ya da süreçlerin iyileştirilmesi gibi konularda bilgi, fikir ve düşüncelerini paylaşmasıyla optimum çözümler geliştirilecektir. Bu bağlamda yöneticiler;

- Astları ile aralarındaki katı statü bariyerlerini kaldırmalı,

- Güvenli bir ortam oluşturmalı ve işgörenlerin konuşmalarını sağlamalı,

- Somut yöntem ve uygulamalarla açık bir iletişim yapısı oluşturmal1,

- Konuşmak isteyen işgörenleri "şikayetçi, sorun çıkarıcı" yerine "cesur, yürekli” olarak göstermeli,

- Sorunların çözümünde ya da süreçlerin iyileştirilmesinde kullanılan fikirleri ödüllendirmelidir.

\section{Kaynakça}

Acaray, A., Çekmecelioğlu, H., \& Akturan, A. (2015). Örgüt Kültürü İle Örgütsel Sessizlik Arasındaki İlişkinin İncelenmesi. The Journal of Academic Social Science Studies, (32), 139-157.

Adeniji, A. A. (2011). Organizational Climate and Job Satisfaction among Academic staff in some Selected Private Universities in Southwest Nigeria. Doktora Tezi. Nigeria: Covenant University.

Aktaş, H., \& Şimşek, E. (2014). Örgütsel Sessizlik Ile Algilanan Bireysel Performans, Örgüt Kültürü Ve Demografik Değişkenler Arasindaki Etkileşim. Akdeniz Üniversitsi Iktisadi ve İdari Bilimler Fakültesi Dergisi, (28), 24-52.

Beheshtifar, M., Borhani, H., \& Moghadam, M. N. (2012). Destructive Role of Employee Silence in Organizational Success. International Journal of Academic Research in Business and Social Sciences, 2(11), 275-282.

Bildik, B. (2009). Liderlik Tarzları, Örgütsel Sessizlik ve Örgütsel Bă̆lllık İlişkisi. Yüksek Lisans Tezi. Gebze: Gebze Yüksek Teknoloji Enstitüsü.

Bitsani, E. (2013). Theoretical Approaches to the Organizational Culture and the Organizational Climate: Exploratory Research Examples and Best Policies in Health Care Services. Journal of Human Resource Management, 1(4), 48-58.

Bogosian, R., \& Stefanchin, J. E. (2013). Silence Is Not Always Consent: Employee Silence as a Barrier to Knowledge Transfer (ss. 1-21). In: Proceedings of the International Conference on Organisational Learning, Knowledge and Capabilities.

Botero, I. C., \& Van Dyne, L. (2009). Employee Voice Behavior: Interactive Effects of LMX and Power Distance in the United States and Colombia. Management Communication Quarterly, 23(1), 84-104.

Büte, M. (2011). Algılanan Örgüt İkliminin Etik Olmayan Davranışlar Üzerindeki Etkilerinin Belirlenmesine Yönelik Bir Araştırma. Atatürk Üniversitesi Iktisadi ve İdari Bilimler Dergisi, 25(2), 103-122.

Çakıcı, A. (2007). Örgütlerde Sessizlik: Sessizliğin Teorik Temelleri ve Dinamikleri. Çukurova Üniversitesi Sosyal Bilimler Enstitüsü Dergisi, 16(1), 145-162.

Çakıı1, A. (2010). Örgütlerde Işgören Sessizliği. Ankara: Detay Yayıncilik.

Cameron, K. S., \& Quinn, R. E. (2006). Diagnosing and Changing Organizational Culture (Revised Edition.). United States of America: Jossey-Bass.

Çavuşoğlu, S. ve Köse, S. (2016). Örgüt Kültürünün Örgütsel Sessizlik Davranişina Etkisi. Dokuz Eylül Üniversitesi Sosyal Bilimler Enstitüsü Dergisi, 18(1), 115-146. doi:10.16953/deusbed.46003

Çekmecelioğlu, H. G. (2011). Algılanan Örgüt İkliminin Çalışanların İş Tatmini, Duygusal Bağlılık ve Örgütsel Vatandaşlık Davranışı Üzerindeki Etkilerinin İncelenmesi. Istanbul Üniversitesi İşletme Fakültesi Işsletme İktisad Enstitüsü Dergisi, 22(68), 29-47. 
Dedahanov, A. T., Kim, C., \& Rhee, J. (2015). Centralization And Communication Opportunities As Predictors Of Acquiescent Or Prosocial Silence. Social Behavior And Personality, 43(3), 481-492.

Durak, İ. (2012). Korku Kültürü ve Örgütsel Sessizlik. Bursa: Ekin Yayınevi.

Ehtiyar, R., \& Yanardağ, M. (2008). Organizational Silence: A Survey on Employees Working in a Chain Hotel. Tourism and Hospitality Management, 14(1), 51-68.

Erdem, R. (2007). Örgüt Kültürü Tipleri ile Örgütsel Bağlılık Arasındaki İlişki: Elazı ğ İl Merkezindeki Hastaneler Üzerinde Bir Çalışma. Eskişehir Osmangazi Üniversitesi IIIBF Dergisi, 2(2), 63-79.

Erdoğan, E. (2011). Etkili Liderlik Örgütsel Sessizlik Ve Performans Iliş̧kisi. Yüksek Lisans Tezi. Gebze: Gebze Yüksek Teknoloji Enstitüsü.

Eroğlu, H., Adıgüzel, O., \& Özü. (2011). Sessizlik Girdabı ve Bağlılık İkilemi: İşgören Sessizliği ile Örgütsel Bağlılık İlişkisi ve Bir Araştırma. Süleyman Demirel Üniversitesi Iktisadi ve İdari Bilimler Fakültesi Dergisi, 16(2), 97-124.

Güçlü, N. (2003). Örgüt Kültürü. Gazi Üniversitesi Sosyal Bilimler Dergisi, 23(2), 61-85.

Gül, H., \& Özcan, N. (2011). Mobbing ve Örgütsel Sessizlik Arasındaki İlişkiler: Karaman İl Özel İdaresinde Görgül Bir Çalışma. Kahramanmaraş Sütçü Imam Üniversitesi İktisadi ve İdari Bilimler Fakültesi Dergisi, 1(2), 107-134.

Holloway, J. B. (2012). Leadership Behavior and Organizational Climate: An Empirical Study in a NonProfit Organization. Emerging Leadership Journeys, 5(1), 9-35.

İşcan, F. Ö., \& Karabey, C. N. (2007). Örgüt İklimi ile Yeniliğe Destek Algısı Arasındaki İlişki. Gazi Üniversitesi Sosyal Bilimler Dergisi, 6(2), 180-193.

İşcan, F. Ö., \& Timuroğlu, M. K. (2007). Örgüt Kültürünün Iş Tatmini Üzerindeki Etkisi Ve Bir Uygulama. Atatürk Üniversitesi İktisadi ve İdari Bilimler Dergisi, 21(1), 119135.

Kahveci, G., \& Demirtaş, Z. (2013). Okul Yöneticisi ve Öğretmenlerin Örgütsel Sessizlik Algıları. Eğitim ve Bilim, 38(167), 50-64.

Karaca, H. (2013). An Exploratory Study On The Impact Of Organizational Silence In Hierarchical Organizations: Turkish National Police Case. European Scientific Journal, 9(23), 38-50.

Karaköse, T., \& Kocabaş, İ. (2006). Özel Ve Devlet Okullarinda Öğretmenlerin Beklentilerinin Iş Doyumu ve Motivasyon Üzzerine Etkileri. Eğitimde Kuram ve Uygulama, 2(1), 3-14.

Keser, A. (2005). Çalışma Yaşamı ile Yaşam Doyumuna İlişkisine Teorik Bakış. İktisat Fakültesi Mecmuası, 55(1), 897-913.

K1lıç, G., Tunç, T., Saraçlı, S., \& Kılıç, İ. (2013). Örgütsel Stresin Örgütsel Sessizlik Üzerine Etkisi: Beş Yıldızlı Termal Otel Işsletmelerinde Bir Uygulama. İşletme Araştırmaları Dergisi, 5(1), 17-32.
Köse, S., Tetik, S., \& Ercan, C. (2001). Örgüt Kültürünü Oluşturan Faktörler. Celal Bayar Üniversitesi. İktisadi ve İdari Bilimler Fakültesi. Yönetim ve Ekonomi Dergisi, 7(1), 219-242.

Kumar, D., Alagappar, P. N., \& Govindarajo, N. (2015). Australian Journal of Basic and Applied Sciences The Impact of Organisational Silence on Job Stress, Organisational Commitment and Intention to Leave Among Expatriate Employees. Australian Journal of Basic and Applied Sciences, 9(29), 1-8.

Kuşcu, P. Ç. (2011). Örgüt Kültürü ve $\dot{I}_{S ̧}$ Yeri Zorbalı̆̆g: $\dot{I}_{S ̧} k u r$ ve Ors Örneği. Doktora Tezi. Ankara: Hacettepe Üniversitesi.

Megenci, C. (2015). Antecedents and Consequences of Organizational Fear and Silence Behavior: Evidence Service Sector from Turkey. International Business Research, 8(5), 223-229.

Milliken, F. J., \& Morrison, E. W. (2003). Shades of Silence: Emerging Themes and Future Directions for Research on Silence in Organizations. Journal of Management Studies, 40(6), 1563.

Morrison, E. W., \& Milliken, F. J. (2000). Organizational Silence: A Barrier to Change and Development in a Pluralistic World. Academy of Management Review, 25(4), 706-725.

Nikolaou, I., Vakola, M., \& Bourantas, D. (2011). The Role of Silence on Employees' Attitudes "The Day After" a Merger. Personnel Review, 40(6), 723-741.

Pinder, C. C., \& Harlos, K. P. (2001). Employee Silence: Quiescence And Acquiescence As Responses To Perceived İnjustice. Research in Personnel and Human Resources Management, 20, 331-369.

Premeaux, S. F., \& Bedeian, A. G. (2003). Breaking the Silence: The Moderating Effects of Self-Monitoring in Predicting Speaking up in the Workplace. Journal of Management Studies, 40(6), 1537-1562.

Sağlık Bakanlığı (2016). T.C. Sağlık Bakanlı̆̆ı Sağlik Istatistikleri Yıllığı 2015. Ankara: Sağlık Bakanlığı Sağlık Araştırmaları Genel Müdürlüğü.

Schneider, B., Ehrhart, M. G., \& Macey, W. H. (2013). Organizational Climate and Culture. The Annual Review of Psychology, 64, 361-388.

Şehitoğlu, Y., \& Zehir, C. (2010). Türk Kamu Kuruluşlarında Çalışan Performansının, Çalışan Sessizliği ve Örgütsel Vatandaşlık Davranışı Bağlamında İncelenmesi. Amme Ídaresi Dergisi, 43(4), 87-110.

Şimşek, E., \& Aktaş, H. (2014). Örgütsel Sessizlik ile Kişilik ve Yaşam Doyumu Etkileşimi: Kamu Sektöründe Bir Araştırma. Anadolu Üniversitesi Sosyal Bilimler Dergisi, 14(2), 121-136.

Tayfun, A., \& Çatır, O. (2013). Örgütsel Sessizlik ve Çalışanların Performansları Arasındaki İlişki Üzerine Bir Araştırma. İşletme Araştırmaları Dergisi, 5(3), 114-134.

Turgut, T. (2011). Çalişmaya Tutkunluk: İş Yükü, Esnek Çalişma Saatleri, Yönetici Desteği Ve İş-Aile Çatişmasi İle 
İlişkileri. Atatürk Üniversitesi İktisadi ve İdari Bilimler Dergisi, 25(3-4), 155-179.

Uçar, Z. (2016). Örgütsel (İşgören) Sessizlik Olgusunun Kişisel ve Demografik Özellikler Bağlamında Araştırılması: Nitel Bir Çalışma. Dokuz Eylül Üniversitesi, Iktisadi ve İdari Bilimler Fakültesi Dergisi, 31(1), 311342.

Ülker, F., \& Kanten, P. (2009). Örgütlerde Sessizlik İklimi, İşgören Sessizliği ve Örgütsel Bağlllık İlişkisine Yönelik Bir Araştırma. Aksaray Üniversitesi İktisadi ve İdari Bilimler Fakültesi Dergisi, 1(2), 111-126.

Vakola, M., \& Bouradas, D. (2005). Antecedents and Consequences of Organisational Silence: An Empirical Investigation. Employee Relations, 27(5), 441-458.

Van Dyne, L., Ang, S., \& Botero, I. C. (2003). Conceptualizing Employee Silence and Employee Voice as Multidimensional Constructs. Journal of Management Studies, 40(6), 1359-1392.

Yalçınsoy, A. (2017). Örgütsel Sessizlik ve Sonuçlari. The Journal of Social Science, 1(1), 1-19.

Yalçınsoy, A. ve Zincirkıran, M. (2016). Örgüt Kültürü ve Örgüt İkliminin Örgütsel Sessizlik Üzerine Etkisinin Analizi (ss. 1187-1195). İçinde: 1st International Conference on Scientific Cooperation for the Future in the Social Science, Uşak.

Yaman, E., \& Ruçlar, K. (2014). Örgüt Kültürünün Yordayıc1s1 Olarak Üniversitelerde Örgütsel Sessizlik. Journal of Higher Education \& Science/Yüksekögretim ve Bilim Dergisi, 4(1), 36-50.

Zhang, J., \& Liu, Y. (2010). Organizational Climate and Its Effects on Organizational Variables: An Empirical Study. International Journal of Psychological Studies, 2(2), 189201. 